\title{
GEORGE WASHINGTON AND THE EXeCUTIVe Power
}

\author{
JOHN YOO*
}

A singular factor influenced the ratification of the Constitution's article on the Presidency: All understood that George Washington would be elected the first President. It is impossible to understate the standing of the "Father of his Country" among his fellow Americans. He had established America's fundamental constitutional principle-civilian control of the military-before there was even a Constitution. Throughout his command of the Continental Army, General Washington scrupulously observed civilian orders and restrained himself when a Congress on the run granted him dictatorial powers. He had even quelled, by his mere presence, a potential coup d'état by his officers in 1783.' Washington cannot be quantified as an element of constitutional law, but he was probably more important than any other factor.

The Revolutionary War had revealed Congress to be feeble, and the states to be unreliable. Washington had exercised broad executive and administrative authorities that went well beyond battlefield command to keep the army supplied. This experience made Washington a firm nationalist who supported a more effectively organized and vigorous national government. Though he barely spoke at the Constitutional Convention, Washington placed his considerable prestige behind the enterprise. During ratification, he launched a one-man letter-writing campaign to encourage Federalists throughout the country, and particularly in his critical home state of Virginia, to win the Constitution's approval. Washington remains the only President to be elected by a unanimous vote of the Electoral College.

Because the American Republic grew so successfully, we tend to treat Washington's decisions with an air of inevitability, but the constitutional

\footnotetext{
" Professor of Law, Berkeley Law School, University of California at Berkeley; Visiting Scholar, American Enterprise Institute. This essay is taken from my CRISIS AND COMMAND: EXECUTIVE POWER FROM GEORGe WASHINGTON TO GEORGE W. Bush (2010). I am grateful to Robert Delahunty for his comments. I thank Meng Xi for excellent research assistance.

1. See Glenn A. Phelps, George Washington and American Constitutionalism 44-46 (1993).
} 
text left more questions about the executive unanswered than answered. Article II vested the executive power of the United States in a single President, but it did not list its components (unlike Article I's enumeration of legislative powers). It did not create any advisors, heads of departments, or a cabinet, not to mention a White House staff; specify how the President should interact with Congress, the courts, or the states; nor describe how the President and the Senate were to exercise their joint powers over treaties and appointments.

Washington filled these gaps with a number of foundational decisions-several on a par with those made during the writing and ratification of the Constitution itself. His desire to govern by consensus sometimes led him to seek cooperation with the other branches. He was a Republican before he was a Federalist, but ultimately Washington favored an energetic, independent executive, even at the cost of political harmony. Washington centralized decision making in his office, so that there would be no confusion about his responsibility and accountability, and his direct orders sped quickly through the small federal bureaucracy. He took the initiative in enforcing the law and followed his own interpretation of the Constitution.

To Washington, the departments and their secretaries served only as "dependent agencies of the Chief Executive." 2 As Leonard White has written, the President made "all major decisions of administration" and took full responsibility for them. ${ }^{3}$ He managed diplomatic relations with other countries and set the nation's foreign policy. At the end of his two terms, the Presidency looked much like the one described in The Federalist. Hamilton's outsized performance as Secretary of the Treasury helped, but the real credit goes to Washington. ${ }^{4}$

None of this was foreordained. Washington could have chosen to mimic a parliamentary system with cabinet secretaries who represented different factions in the legislature or a balanced government with executive branch officials drawn from an aristocratic social class. He could have assumed the function of a head of state and given department secretaries freedom over their jurisdictions or he could have perceived the Presidency as Congress's clerk, draining any initiative from the job and committing himself solely to carrying out legislative directions. He might even have thought of himself as the servant of the states (he certainly did not; on a trip to Boston, President Washington refused to call on Governor John

2. Mark J. Rozell, William D. Pederson, \& Frank J. Williams, George WASHINGTON AND THE ORIGINS OF THE AMERICAN PRESIDENCY 58 (2000).

3. Leonard D. White, The Federalists: A Study IN Administrative History 27 (1948).

4. PHELPS, stupra note 1 , at $145-49$. 
Hancock, instead forcing an ill Hancock to come to him first). ${ }^{5}$

Washington ranks in the most recent scholarly poll as our nation's greatest President. Some might think that his high standing rewards him, like Jefferson, for his achievements before he assumed office, but this view understates the second source of his greatness-establishing a stable government under law that has endured to this day. Washington led the nation through its first growing pains; restored the country's finances; kept the nation out of a dangerous European war; opened the West to American expansion; and saw the Constitution through the appearance of the first political parties (something the Framers did not foresee and would have opposed). Washington did all of this without seeking popularity and without enjoying what we would think of today as political talents. He was a natural leader, one of the finest horsemen of his age, and a tall and strong man. $\mathrm{He}$ had single-handedly ended a riot among northern and southern soldiers on Boston Commons by grabbing the leaders in each hand and shaking them into submission. Washington was stern, distant, and concerned above all about his reputation. He carried himself with gravitas, projected a demeanor of republican simplicity and virtue (hence the fable about the cherry tree), and yet struggled his whole life to control a ferocious temper. Every President since Washington's day has had the impossible task of measuring up to his founding example.

\section{Establishing the Presidency}

After his election in early 1789 , Washington took his time getting to the nation's capital in New York City. He wanted to give Congress time to count the electoral votes, avoid the appearance of unseemly eagerness, and allow the people to see the physical symbol of the new national government. Once installed, Washington made clear who was in charge.

Three approaches to organizing the Executive Branch existed. ${ }^{6}$ First, some Senators believed they would share administrative authority because of their say over appointments and the example set by the state advisory councils. A second view, identified with Alexander Hamilton, held that department heads would perform the same positions as ministers in Great Britain; they would exercise significant independent discretion and coordinate the making of policy in Congress and its implementation by the executive. Washington chose a third, which resembled the organization of his military command. The President alone would exercise the executive power. He would receive advice from his department secretaries, who

5. The story of the Washington-Hancock tiff is retold in JAMES T. FLEXNER, GEORGE WASHINGTON AND THE NEW NATION: 1783-1793, at 230 (1970).

6. See Forrest MCDONALD, The PRESIDENCy OF GEORGe Washington 39-40 (1974). 
would supervise the inferior officers in their agencies. All matters of executive policy would come to him. He would either make all significant decisions or delegate them. Administration to Washington, in the words of historian Forrest McDonald, was "highly personal, after the fashion of the pre-bureaucratic eighteenth-century world."

Washington's initiative became apparent within a month of his inauguration. Even though there were no federal laws to enforce or positions to fill, Washington quickly took over the existing administrative machinery of the Articles of Confederation. He ordered the ministers of war and foreign affairs and the Board of Treasury to provide him with "an acquaintance with the real situation of the several great Departments, at the period of my acceding to the administration of the general Government" and a "full, precise, and distinct general idea of the affairs of the United States." $\mathrm{He}$ made clear that subordinate Executive Branch officials were his assistants, rather than independent power centers. Washington wrote that the "impossibility that one man should be able to perform all the great business of the State, I take to have been the reason for instituting the great Departments, and appointing officers therein, to assist the supreme Magistrate in discharging the duties of his trust."

Washington could not have accomplished this alone. He had a willing and able ally in the 38-year-old Congressman from Virginia, James Madison. Even though Madison had played the leading intellectual role in the drafting of the Constitution, co-written the newspaper editorials that would become The Federalist, and led the forces for ratification in the Virginia convention, he had barely won election to the House due to Patrick Henry's opposition. Once there, Madison promoted Washington's policies-a position that would not last into the second term. Madison is what we would today think of as a coalition builder: organizing behind the scenes, ceding political credit to others, acting through committees and larger bodies, yet always moving others toward his preferred goal. What he lacked in political gifts-he was short, fearfully shy, and weak-voiced-he more than made up for in his genuine intellect, willingness to work the longest hours, and meticulous preparation. It is no wonder that he has always been a favorite of scholars.

Madison took the lead in enacting legislation to establish the government, from the constitutional amendments that became the Bill of Rights to the first direct national taxes in American history. Madison

7. Id. at 39 .

8. 30 WRITINGS OF GEORGE WASHINGTON 344 (John C. Fitzpatrick ed., 1939).

9. Id. at 334. For the view that Washington's move to control the machinery of the Continental Congress is more ambiguous because of the unusual change between forms of government, see Curtis Bradley \& Martin Flaherty, Executive Power Essentialism and Foreign Affairs, 102 MICH. L. REV. 545, 637-41 (2004). 
likewise managed the debate over the establishment of the first great executive departments, what Daniel Webster would later call the "Decision of 1789."10 The key issue concerned the authority to remove the heads of the departments of Foreign Affairs, War, and the Treasury. Four possibilities existed. First, the Constitution may have intended that the President exercise the power alone, with the Senate's role in confirmation being the sole exception to his general control over appointments. Second, it could have reserved the right to the President and Senate together, under the idea that the same process should be used to reverse a decision as to make it. Third, removal might only occur through impeachment. Or, fourth, the Constitution could leave the power to Congress, as part of its power under the Necessary and Proper Clause to establish the departments in the first place.

Decision of this question had profound implications for presidential control of the executive branch. The constitutional text is silent as to whether cabinet officers must obey presidential orders, and chief executives to this day back up their commands with the implicit threat of removal. If cabinet members could only be removed by impeachment, or with the advice and consent of the Senate, they would feel little fear when ignoring presidential directives. Congress also recognizes this relationship between removal and control, and, since the New Deal, has tried to impose conditions on the removal of officials who work for the independent agencies. The 1978 Ethics in Government Act, for example, created an independent prosecutor by prohibiting his or her removal except for committing a felony or other violation of the law. ${ }^{11}$ Impeachment or congressional discretion over removal would have created even greater disruption by transferring effective control over subordinate executive officials to the legislature. Only an inherent removal power in Article II's undefined grant of the executive power allowed control of subordinate officers by the President.

When Congress took up the issue of national finance on May 19, 1789, Madison proposed the creation of three departments: War, Foreign Affairs, and the Treasury. Each department would have a Secretary, appointed by the President with the advice and consent of the Senate, but removable by the President alone. ${ }^{12}$ Amendments to require Senate approval of removals failed, and Madison's proposal won a considerable majority. ${ }^{13}$ Specific bills detailing each department's functions came before Congress a month later, whereupon opponents of executive power again attempted to strike

10. Myers v. United States, 272 U.S. 52, 151 (1926) (quoting Daniel Webster).

11. Ethics in Government Act of 1978, Pub. L. No. 95-521, 92 Stat. 1978.

12. 10 DOCUMENTARY HISTORY OF THE FIRST FEDERAL CONGRESS, 1789-1791, at 718-20 (Charlene Bangs Bickford et al. eds., 2004).

13. Id. at $738-40$. 
recognition of the President's removal authority.

Madison argued that the President's standing as Chief Executive gave him the inherent power to fire subordinates. "Is the power of displacing an executive power?" Madison asked the House on June 16. "I conceive that if any power whatsoever is in its nature executive it is the power of appointing, overseeing, and controlling those who execute the laws." 14 The Constitution only allowed a single exception to the President's power in the Senate's advice and consent function. Congress could not add others. "If the [C]onstitution has invested all executive power in the President," Madison said, "I venture to assert that the Legislature has no right to diminish or modify his executive authority." 15

While there were dissenters, the First Congress clearly believed that Article II's vesting of the executive power in the President was more than a stylistic device. Madison's supporters amended the bills to clarify that Congress was not granting the President the power to remove, but only recognizing his constitutional authority to do so. ${ }^{16}$ In the Senate, which we would expect to be more jealous of its prerogatives, the removal provision encountered more difficulties. The Senate deadlocked 10-10 on the bills to create the Departments of Foreign Affairs and War because of the removal question. Vice President Adams broke both ties in favor of the House versions, handing the administration a victory. The Treasury bill raised a different variation of the executive power issue. Critics thought the power of the Department was too great, particularly its authority to "digest and prepare plans for the improvement and management of the revenue, and the support of the public credit," which they believed properly rested within Congress's power of the purse. They sought to divide leadership of the Treasury into a board, as under the Articles of Confederation, and to limit the President's removal power because the Department exercised legislative powers. Again, Madison succeeded in convincing the House to create a Treasury Department with maximum authority and energy, but within the President's control, and again the Vice President broke a Senate tie in the administration's favor. ${ }^{17}$

14. Id. at 868 .

15. Id.

16. I have been guided through the various debates and changes in the statutory proposals by Saikrishna B. Prakash, New Light on the Decision of 1789, 91 CORNELL L. ReV. 1021, 1029-34 (2006). The debate is also recounted prominently by DAVID CURRIE, THE CONSTITUTION IN CONGRESS: The Federalist PERIOD 1789-1801, at 36-41 (1997); see also ChARLES C. THACH, Jr., The Creation OF THE PresidenCy, 1775-1789, at 140-65 (1923); and JAMES Hart, The AMERICAN PRESIDENCY IN ACTION 1789, at 155-89 (1948).

17. Some have argued that Congress's actions indicate that the Treasury Department was not even an executive department, but rather an administrative agency outside of direct presidential control. See Lawrence Lessig \& Cass R. Sunstein, The President and the Administration, 94 Colum. L. REv. 1, 28 (1994). Steven Calabresi and Sai Prakash have shown their arguments on this score to be off the mark. See Steven G. Calabresi \& Saikrishna B. Prakash, The President's 
Members of the legislative and executive branch would recognize that the "Decision of 1789" represented Congress's own constitutional understanding of the President's executive authority to remove subordinate officials. In the course of the debate, supporters of presidential removal argued that the Chief Executive bore the constitutional obligation to execute the laws. This required that subordinates aid him "in the administration of his department." ${ }^{\prime 8}$ The President's power to remove gave him the power to make sure that these officials enforce the laws as he wished. Giving Congress or the Senate a role in removal would make the President a "mere vapor" and would place "the Legislature at the head of the Executive branch." 19 As Madison wrote to Jefferson, the House vote was "most consonant to the text of the Constitution, to the policy of mixing the Legislative and Executive Departments as little as possible, and to the requisite responsibility and harmony in the Executive Department.,"20

Washington's cabinet nominations met far less opposition than the creation of their offices. Hamilton was nominated, confirmed, and took office as Secretary of the Treasury all on September 11, 1789. Henry Knox was confirmed as Secretary of War the next day, and Thomas Jefferson was nominated for Secretary of State two weeks later and was confirmed in a day. In choosing these officials, Washington did not pursue the same objectives as Presidents today.

Washington did not become President as the head of a political party and did not campaign for a "mandate," nor did he seek nominees who agreed with a particular program or agenda. Washington chose men he called the "first Characters," who had already held positions of trust in state government, the Confederation, or the Continental Army. They were to be both strong on merit and geographically diverse. Washington believed that selecting nominees who were held in the highest regard in their communities would encourage respect and "affection" for the new national government. ${ }^{21} \mathrm{He}$ balanced the major cabinet appointments among Virginia, New York, and Massachusetts; his Supreme Court nominees hailed from six different states. His interest in "first Characters" at times outweighed his interest in harmonious relations: Hamilton and Jefferson quickly became

Power to Execute the Laws, 104 YALE L.J. 541 (1994). Indeed, Madison's arguments in the House that the Treasury Department ought to be unified under one secretary accountable to the President defeats their claim. For some interesting applications of this theme to Congress and the federal courts, see Saikrishna Prakash, Removal and Tenure in Office, 92 VA. L. REV. 1779 (2006). For the claim that the Decision of 1789 is more ambiguous, see Bradley \& Flaherty, supra note 9, at 656-64.

18. 1 ANNALS OF CONG. 379 (1789) (Joseph Gales ed., 1834).

19. Id. at 463,547 .

20. Letter from James Madison to Thomas Jefferson (June 30, 1789), in 16 DOCUMENTARY HISTORY OF THE FIRST FEDERAL CONGRESS, supra note 12 , at 890,893 .

21. Stanley M. Elkins \& Eric L. MCKitrick, The age of Federalism: The Early AMERICAN REPUBLIC, 1788-1800, at 53-54 (1993). 
deeply divided over economic and foreign policy, such that Washington did not even have his cabinet meet as a group until his second term under the pressures of the French Revolution. ${ }^{22}$ Nominees had to be "friends" of the national government; no Anti-Federalists would assume federal office. While making his first appointments, Washington wrote that he would not "bring a man into office . . . whose political tenets are adverse to the measures which the general government are pursuing." This, he believed, would be "a sort of political Suicide." 23

Given his interest in local reputations, Washington might have welcomed the Senate's participation before selection of a nominee. Article II's advice-and-consent structure might have given rise to a joint Senate role in choosing the nominees-otherwise, what would distinguish "advice" from "consent"? ${ }^{24}$ But Washington would have none of it. Even before he had chosen his cabinet officers, Washington had assumed the responsibility of nominating customs collectors, who would represent the national government in every major city and port. For Savannah, Washington chose a former revolutionary army officer named Benjamin Fishbourne, who was serving in the same capacity for the state of Georgia. Fishbourne became the first nominee to be rejected by the Senate.

The Senate adopted a resolution seeking face-to-face meetings with the President for every open office and appointed a committee to meet with Washington to work out the procedures. Washington promptly nominated another candidate and rebuffed the idea of formally meeting with the Senate to choose executive officers. He wanted to make clear that he was the Chief Executive, and that members of the executive branch were his assistants. While Presidents, including Washington, have always informally consulted with members of Congress in selecting federal officers and judges, they have ever since relegated the Senate's constitutional function to the approval of their nominees.

Once installed, cabinet members understood that Washington was responsible for the actions of the entire executive branch. Writing to his own administration twelve years later, Jefferson described Washington as sending a stream of questions, requests, and orders to his department secretaries, and meeting with each of them on a regular basis, usually over

22. Forrest McDonald, The American Presidency: AN Intellectual History 227 (1994).

23. Letter from George Washington to Henry Knox (Sept. 20, 1795), in 34 WRITINGS of GEORGE WASHINGTON, supra note 8, at 315 .

24. Various Senators and commentators have urged such a role for the Senate over the years. See, e.g., David A. Strauss \& Cass R. Sunstein, The Senate, the Constitution, and the Confirmation Process, 101 YALE L.J. 1491, 1502-12 (1992). Arguments against include John O. McGinnis, The President, the Senate, the Constitution, and the Confirmation Process: A Reply to Professors Strauss and Sunstein, 71 TEX. L. REv. 633, 638-39 (1993). 
breakfast, to discuss matters until he was fully satisfied. ${ }^{25}$ This unending circulation of reports, letters, and paperwork-backed up by the President's constitutional authority to require "opinions in writing"-kept him "always in accurate possession of all facts or proceedings in every part of the Union, and to whatsoever department they related."26 Washington "formed a central point for the different branches," Jefferson wrote, allowing the President to promote "unity of object and action among them." Given his wartime experiences, as Forrest McDonald has observed, Washington felt little need to delegate foreign or military affairs, sometimes reducing Jefferson and Knox to the status of glorified clerks. ${ }^{27}$

Hamilton exercised unusual leadership over the establishment of the national bank not because of any constitutional or statutory independence, but because Washington was uninterested in finance. Washington also trusted Hamilton because of his wartime service as his trusted aide-de-camp and the recommendation of Robert Morris, who had overseen revolutionary finances. Hamilton's grand design was unique in another respect. It was the only time that the administration managed legislation through Congress. In general, Washington took a hands-off approach to the legislature. In his first annual address to Congress (delivered in person), he put aside his original plan to propose legislation and instead spoke generally about commerce, farming, and manufacturing; promoting science and the arts; and implementing the Constitution. ${ }^{28} \mathrm{He}$ questioned whether he could do anything more. "It rests with [Congress] to decide what measures ought afterwards to be adopted for promoting the success of the great objects, which I have recommended to their attention." ${ }^{29}$ Today's practice of lobbying Congress or threatening a veto to affect policy outcomes would have been quite foreign to our first President.

Creating the nation's financial system was the exception. Hamilton proposed that the national government assume the wartime debts owed by the Confederation and the states. To repay at close to face value, Hamilton wanted to issue bonds funded by new taxes on imports. His plan essentially refinanced the national debt by consolidating multiple loans into one large, regular mortgage payment. Hamilton believed that the creation of a permanent debt would lead to a stable currency (in the form of government notes), expand credit within the economy, and give the financial and merchant classes (who would hold the notes) a stake in the government's

25. See generally WRITINGS OF THOMAS JEFFERSON (Paul Leicester Ford ed., 1904).

26. Letter from Thomas Jefferson to Heads of Departments (Nov. 6, 1801), in 9 WRITINGS OF THOMAS JEFFERSON, supra note 25, at 310-12.

27. MCDonald, The Presidency of George Washington, supra note 6 , at 41 .

28. See PHELPS, supra note 1 , at 140-41.

29. Letters from George Washington to Baron Poellnitz (Mar. 23, 1790), in 31 WRITINGS OF GEORGE WASHINGTON, supra note 8, at 23-24. 
success. Hamilton also believed a national bank was necessary to loan the government money, handle its interest payments, and manage open-market transactions in government bonds. ${ }^{30}$ Assumption of the state debt made it through the first Congress, but only after Hamilton, Jefferson, and Madison had reached a deal over dinner. Jefferson supported the financial legislation when Hamilton agreed that the national capital would rest on the Potomac. ${ }^{31}$

Hamilton worked tirelessly to build public and congressional support for his grand design. While the core of Congress's constitutional powers lay in the purse strings, the complexity of public finance and spending caused legislators to passively vote up or down on Hamilton's initiatives. Still, Hamilton's plan caused Washington to consider the first use of the veto. Madison and Jefferson worried that the proposed system would duplicate Britain's corrupt political and social system. Influenced by British oppositionist ideology, they associated a national bank with the Crown's influence over Parliament, the movement of economic power away from farms to the cities, and the rise in the political power of the financial classes. Even as Hamilton's proposal passed both houses overwhelmingly, Madison attacked it for lacking any specific textual basis in the Constitution and exceeding the Necessary and Proper Clause. ${ }^{32}$ Madison reversed his anonymous position in The Federalist, where he had argued in favor of a broad reading of the federal government's powers. ${ }^{33}$

Washington asked Jefferson and Attorney General Edmund Randolph for their opinions, and even asked Madison to draft a veto message. Randolph concluded that the Tenth Amendment limited the powers of Congress to set up a bank. Jefferson argued that the creation of a bank was not "necessary" to achieve a legitimate purpose, and that to give the Necessary and Proper Clause a broader construction would burst the Constitution's careful limits on national power ${ }^{34}$ Hamilton responded that the Clause was a grant of power that allowed the government to enact means that were not just "necessary," but useful. The Necessary and Proper Clause empowered the government, rather than limiting it to steps that were absolutely indispensable. ${ }^{35}$ Hamilton's opinion would strongly influence the Supreme Court's holding in McCulloch v. Maryland, which upheld the constitutionality of the bank twenty years later. ${ }^{36}$ Washington signed the bill two days after he received Hamilton's written opinion.

30. I have found invaluable Forrest McDonald's analysis of the Hamiltonian system, and its political effects, in MCDOnald, The PrEsidency of GEORge Washington, supra note 6, at 47-88.

31. ELKINS \& MCKITRICK, supra note 21, at 155-61.

32. U.S. CONST. art I, $\S 8$, cl. 18.

33. FEDERALIST No. 44, at 302-05 (James Madison) (Jacob E. Cooke ed., 1961).

34. 19 The PAPERS OF ThOMAS JeFFERSON 275-80 (Julian P. Boyd ed., 1974).

35. 8 The PAPERS OF AleXANDER HAMILTON 63-134 (Harold Syrett ed., 1965).

36. McCulloch v. Maryland, 17 U.S. 316 (1819). 
Washington understood the President to have the independent right to decide on a bill's constitutionality. If he had deferred to Congress, he would not have asked his cabinet, and he did not think of waiting on the courts to decide. Washington appears to have believed that he should only veto legislation he thought clearly violated the Constitution. Jefferson himself had advised Washington to use the veto only if his mind was "tolerably clear" on the bill's unconstitutionality. ${ }^{37}$

Washington did not issue a veto until 1792 for a bill that allocated Representatives to different states in a clear violation of the Constitution's requirement that every state receive no more than one member for every 30,000 citizens. ${ }^{38}$ While Washington left behind no written thoughts about the veto, it seems that his reasoning was similar to the logic of Federalist $78^{39}$ and Marbury v. Madison. ${ }^{40}$ As the delegation of authority from the people to their political agents, the Constitution represents the highest law. No branch of the government can engage in any act that breaches its terms. A President has a constitutional duty to use his powers, including the veto, to prevent violations of the Constitution. As Jefferson wrote in his bank opinion, the veto was "the shield provided by the [C]onstitution" to prevent Congress from exceeding its enumerated powers. ${ }^{41}$

Washington did not seek to transform his veto into a broader right to advance his policy views. Glenn Phelps argues that Washington signed legislation on international trade and senatorial pay that ran strongly against his own policy preferences. $^{42}$ Still, Washington did not believe his legislative function was limited to guarding the Constitution. His only other veto blocked spending legislation with no constitutional infirmity. In the last days of his Presidency, Congress passed a bill eliminating two cavalry units on the western frontier. This clearly rested within Congress's constitutional authority to raise and fund the military, but Washington nonetheless rejected the bill because it immediately stopped the pay of troops far away on the frontier, where they were most needed. ${ }^{43}$ Washington thought Congress's plan made for poor military strategy, something he knew more about than anyone in the United States.

\section{ENFORCING THE LAW}

Washington did not believe that his executive power was limited to the

37. 19 PAPERS OF THOMAS JEFFERSON, supra note 34, at 280.

38. 32 WRITINGS OF GEORGE WASHINGTON, supra note 8 , at 16-17.

39. FEDERALIST No. 78 (Alexander Hamilton).

40. Marbury v. Madison, 5 U.S. 137 (1803).

41. 19 PAPERS OF THOMAS JEFFERSON, supra note 34, at 280.

42. PHELPS, supra note 1 , at 151-52.

43. Id. at $153-54$. 
hiring and firing of officials. Procedural in nature, that view places the President in charge of all of the personnel within the departments and agencies, but does not recognize any powers of substance. An important constitutional dimension of the Presidency, however, flows through Article II's requirement that the President "shall take care that the Laws be faithfully executed." ${ }^{.44}$ While Presidents have believed that the Take Care Clause includes the interpretation and enforcement of federal law, critics have argued that it only acts to prohibit the President from suspending a law duly enacted by Congress. ${ }^{45}$ Under this theory, Article II's vesting of the executive power mandates only a single President, and not much else. More sophisticated scholars, such as Lawrence Lessig and Cass Sunstein, maintain that Congress's power to establish the agencies includes the right to decide who is to enforce federal law, even so far as to vest the execution of law in entities independent of the President. ${ }^{46}$

This was not Washington's view. He believed that the executive power held both substantive and procedural dimensions. The President's primary authorities of substance centered in foreign and military affairs, but a significant part was domestic. Washington believed that a combination of his authority as Chief Executive and the Take Care Clause gave him the power and responsibility to carry out federal law. This included directing anyone, regardless of his position, who might participate in enforcing the law. Washington even set precedents followed by no other President after him in his vigorousness, such as personally leading troops in a show of force against a rebellion.

Scholars have long observed that the Constitution leaves unclear where "administration" falls among the executive, legislative, and judicial branches. For Washington, that function lodged with the Presidency, just as Hamilton had argued in The Federalist. Our first President believed it crucial to set a visible precedent of vigorous and effective execution of the laws to contrast the strength of the new national government with the weaknesses of the old. Washington's choices were all the more important because of the First Congress's great mass of legislative activity. Unlike its predecessor, the First Congress immediately exercised many of its enumerated powers. It established the executive departments, the federal courts, tax and customs rules, a system for the sale of the western lands, intellectual property rights, bankruptcy regulations, and navigation rules. Some functions were performed by "mongrel" offices (Randolph's description of the Attorney General because it lacked a department) that fit

44. U.S. CONST. art. II, $\S 3$.

45. See, e.g., Am. Bar Ass'n, Task Force on Presidential Signing Statements and the Separation of Powers Doctrine 5 (2006), available at http://www.abanet.org/op/signing statements/aba_final_statements_recommendation-report_7-24-06.pdf.

46. See generally Lessig \& Sunstein, supra note 17. 
uneasily in a clean tripartite separation of powers. ${ }^{47}$ The Post Office seems to have operated with significant independence; federal prosecutors were appointed by the courts and reported to the Secretary of State; and the Secretaries of War and State and the Attorney General reviewed patent applications. ${ }^{48}$ But the great mass of federal law was to be carried out by the new departments, with the Treasury having the greatest number of employees (500 versus 22 in the other departments) to collect taxes and customs duties. Washington took control of these officials from the very start.

As with Shays' Rebellion, Americans' suspicion of taxes put the young government to the test. One of the subroutines of Hamilton's financial program imposed an excise tax on the manufacture of liquor. Whiskey was an important article of commerce, going beyond the impressive drinking ability of Founding-era Americans. Distilling allowed western farmers to transform their crops into a more transportable form, to the point where whiskey even served as a form of frontier currency. After Congress adopted the tax in 1791, protests occurred in the western parts of Pennsylvania (one of the leaders was Albert Gallatin, who would become Jefferson's Treasury Secretary), Virginia, Kentucky, and the Carolinas. Armed resistance broke out three years later, the first significant internal challenge to the new federal government. It would not be the last time that Americans would break the law to defend their beverage of choice. ${ }^{49}$

Washington employed a strategy of political patience backed up by the threat of force. When trouble first arose, he issued a proclamation declaring that resistance to the tax was "subversive of good order, contrary to the duty that every citizen owes to his country, and to the laws, and of a nature dangerous to the very being of a government." ${ }^{50}$ Citing his authority under the Take Care Clause, Washington ordered all courts and officials to enforce the tax and to punish lawbreakers. He sent a note to state governors expressing his "entire confidence" that they would "cheerfully" promote "a due obedience to the Constitutional Laws of the Union."st Governors were not even officers of the federal government, but Washington believed that

47. WHITE, supra note 3 , at 164.

48. See Jerry Mashaw, Recovering American Administrative Law: Federalist Foundations, 1787-1801, 115 YALE L.J. 1256 (2006); and WHITE, supra note 3.

49. The discussion of the Whiskey Rebellion is taken from ELKINS \& MCKITRICK, supra note 21, at 461-88; MCDONALD, supra note 6, at 145-47; and PHELPS, supra note 1, at 131-36. A sustained scholarly treatment can be found in THOMAS P. SLAUGHTER, THE WHISKEY REBELlion: Frontier EpILOGUe to THE AMERICAN REVOLUTION (1988), and a recent journalistic retelling in WILLIAM HOGELAND, THE WHISKEY REBELLION: GEORGE WASHINGTON, Alexander Hamilton, AND THE Frontier Rebels Who Challenged AMERICA'S NEWFOUND SOVEREIGNTY (2006).

50. Proclamation of September 15, 1792, in 32 WRITINGS OF GEORGE WASHINGTON, supra note 8 , at 150 .

51. Id. at 533. 
he could command them to enforce the law.

Washington then adopted a wait-and-see attitude. Congress amended the law to moderate, but not eliminate, tax enforcement, and Hamilton experimented with measures to encourage compliance. Armed resistance still broke out in the summer of 1794, when tax officers began to issue arrest warrants in western Pennsylvania, with trials to be held across the state in distant Philadelphia. About 500 militiamen skirmished with a dozen regular soldiers and burned the home of the federal tax inspector on July 16. On August 1, about 7,000 armed men marched on Pittsburgh; federal officials fled to escape tarring and feathering. ${ }^{52}$

Washington believed he had a personal responsibility to enforce the law. Hamilton, Knox, and Attorney General William Bradford recommended calling out the state militias under federal control, while Randolph, now Secretary of State, urged reconciliation through a federal commission. $^{53}$ Washington took both courses. The Constitution gives Congress the authority to provide for the calling of the militia to "execute the Laws of the Union, suppress Insurrections and repel Invasions." the 1792 Militia Act, the President can call out the militia once a federal judge finds that forces too powerful for the courts are blocking enforcement of the law.

The administration provided the facts of the rebellion to Justice James Wilson, who made the required findings. On August 7, Washington issued a proclamation that the western Pennsylvania area was in a state of insurrection, ordered the rebels to return to their homes, and declared his intention to call out the militia. He ordered 12,500 troops from Maryland, New Jersey, and Virginia in addition to Pennsylvania. Washington also sent commissioners to offer amnesty to any who would swear an oath to obey the laws. His strategy was remarkably successful: A large majority took the oath, while an army of nearly 13,000 (the popular call for troops met with more volunteers than asked) rode through the area in September. They found only twenty rebels, the rest having scattered..$^{55}$

Washington had moved swiftly, issuing his proclamation and calling out the militia only six days after the attacks on federal officials began. He had not waited for federal judges to trigger the Militia Act, but instead went directly to Justice Wilson for a finding of insurrection. He had not consulted Congress, but instead limited discussion of the options to his cabinet, from whom he ordered opinions, and to the state governors, who had to supply the troops. His relationship with the governors is particularly instructive. Under the Articles of Confederation, the governors and legislatures of the

52. ELKINS \& MCKITRICK, supra note 21 .

53. Id. at 481 .

54. U.S. CONST. art. I, $\S 8, \mathrm{cl} .15$.

55. ELKINS \& MCKITRICK, supra note 21. 
states routinely ignored requests for legislation or supplies made by the Continental Congress. Washington turned this unhealthy relationship upside down. When Pennsylvania's governor claimed that a resort to force was unjustified, Washington responded that the nation's response would not depend on the state's views, and ordered him to supply militia to serve under federal command. Washington believed that when state governors enforced federal law, they were subordinate to him, even if he could not remove them.

Washington led the army personally. He rode at the head of the troops, followed by Hamilton and the governor of Pennsylvania, in a show of the new government's strength. Washington's actions were remarkably popular - far beyond anything his cabinet had anticipated-and he followed them with a message to Congress that described the resistance as an insurrection, treason, and a challenge to federal authority. ${ }^{56}$ Congress so approved of Washington's careful use of his powers that it permanently reenacted the Militia Act in 1795 and removed the 1792 Act's requirement that the President seek judicial approval before calling out the militia-all that was required now was a presidential proclamation. ${ }^{57}$

A less dramatic, but equally revealing, episode in the aftermath of the Whiskey Rebellion further illustrates Washington's control of all aspects of federal law enforcement. Defending the modern independent counsel law, today's critics of executive power argue that prosecution does not fall within presidential control. They have pointed to the fact that in 1789 , Congress created no Justice Department-the Attorney General was the sole officer whose job was to advise the President and to represent the United States before the Supreme Court. In the first Judiciary Act, Congress placed the appointment of federal district attorneys in the courts and did not make them explicitly responsible to the Attorney General or the President. Washington did not believe this made federal prosecutors independent. After the Whiskey Rebellion, he ordered Pennsylvania's federal prosecutor to drop the cases against two rebels, and after his Neutrality Proclamation (to be discussed shortly), Washington directed U.S. attorneys to collect information and prosecute violators. ${ }^{58}$ This is not to say that Washington

56. A debate among historians continues to this day about the sources of the Whiskey Rebellion. McDonald has argued that Hamilton deliberately provoked a confrontation in order to create the opportunity for a show of force by the federal government. Others have argued that the sources were primarily economic, in that the tax hit certain classes of western farmers particularly hard, while recent scholarship argues that the Whiskey Rebellion was the product of a number of social and political developments in the West that led to an uprising that was more popular in its roots.

57. See Stephen I. Vladeck, Note, Emergency Power and the Militia Acts, 114 YALE L.J. $149,161-63$ (2004).

58. 32 Writings OF GeORge WASHINGTON, supra note 8, at 455 (Whiskey Rebellion); and at 386 (Neutrality Proclamation). 
exercised the type of centralized control over prosecution that Presidents do today. Given the distances of communication and travel, local federal officials enjoyed a broad discretion that their modern counterparts can only dream of exercising. ${ }^{59}$ Still, Washington believed he could issue direct orders to anyone who carried out federal law, and none of those on the receiving end appears to have disagreed.

The handling of the Whiskey Rebellion rebels set another important law enforcement precedent that counterbalanced the legislature's plenary control over domestic legislation. Just as the President can direct the prosecution of cases to the letter of the law, he can also moderate the law's harshness. Washington's decision to drop the two Whiskey Rebellion cases made clear that he possessed the discretion to choose which cases to prosecute and which to let go. The executive branch would not seek to punish every infraction of federal law. Prosecutorial decisions would be based on a host of considerations, such as the resources available, deterrent effect, retribution, and the seriousness of harm. Under President Jefferson, these considerations would include disagreements with Congress over the policies and constitutionality of the criminal law. A President could refuse to prosecute offenders of a law that he believed violated the right to freedom of speech or religion, even if Congress disagreed.

Washington's offer of amnesty also revealed an important presidential power-to stay a mechanical application of the law to yield more important national benefits. The Constitution's grant of the pardon power could have been read to allow the President only to release individuals already convicted of a crime, though historical evidence suggests that the Framers believed it would be used to offer rewards to criminal conspirators who cooperate with the government. ${ }^{60}$ Washington used the pardon power for a broader purpose, that of restoring order and allowing the government to show magnanimity. Nothing in the Constitution explicitly thrust these goals on Washington, but as Chief Executive he took the establishment of a strong government and the protection of the national interest to be his unique responsibilities. It is a sign of how strongly Washington shaped the office that even today we automatically assume that Presidents enforce the laws guided by their own understanding of the public good.

59. See Calabresi \& Prakash, supra note 17 , at 659 n. 547 ; see also Harold J. Krent, Executive Control over Criminal Law Enforcement, 38 AM. U. L. REV. 275 (1989).

60. See, e.g., David Grady Adler, The President's Pardon Power, in INVENTING THE AMERICAN PRESIDENCY 209 (Thomas E. Cronin ed., 1989). 


\section{Protecting the NAtion: Foreign Affairs AND the WARS OF EUROPE}

Presidents owe their privileged position in foreign affairs not to politics alone, but to the Constitution and to our first President. Washington established from the beginning that the executive branch would assume the leading role in developing and carrying out foreign policy. He did not go unchallenged. In defending Washington's foreign policy initiatives, Hamilton first publicly argued that the President is vested with all of the government's executive power, except that specifically transferred to another branch by the Constitution. Presidents ever since have taken the initiative in foreign affairs by relying on their constitutional powers.

The Constitution's text does not explicitly grant much to the President beyond the undefined executive power, the Commander-in-Chief role, and the right to receive ambassadors. He must share the treaty and appointment powers with the Senate, while Congress receives the powers to declare war and issue letters of marque and reprisal (government permission to privateers to conduct hostilities against an enemy), to raise and fund the military, and to regulate foreign commerce, among other powers. There have been periods where early Presidents deferred to Congress's foreign policy leadership, though with poor results-witness President Adams and the 1798 Quasi-War with France, or President Madison and the War of 1812. Indeed, the conventional wisdom among many legal scholars is that the Constitution gives Congress control over foreign affairs, and that Presidents have inappropriately seized power over war and peace. ${ }^{61}$ As a practical matter, however, the President today can launch the nation into war without explicit congressional consent, enter or end international agreements, interpret international rules on behalf of the United States, and control diplomatic relations with other nations. These decisions, from President Truman's decision to wage the Korean War to Jimmy Carter's termination of the mutual defense treaty with Taiwan, have sparked political controversy and claims of presidential overreaching.

It might not have been Washington's original intention to develop the executive so completely, because he devoted much of his first term to establishing the national government, appointing its officers, and fixing the nation's finances. When he turned to foreign affairs in the early months of his Presidency, he seemed to think that the Senate would perform the role of an advisory council on diplomatic matters. In contrast to his approach to appointments, where he considered the Senate's role to be limited to review

61. See, e.g., LouIS HENKIN, FOREIGN AfFaIRS AND THE U.S. CONSTITUTION (2d ed. 1996); Harold Hongu KoH, THe NaTional Security Constitution: Sharing POWER after THE IRAN-Contra Affair (1990); Michael J. Glennon, Constitutional Diplomacy (1990). 
of his nominations, Washington apparently believed that the Constitution required him to consult with the Senate before sending ambassadors to negotiate. As we will see, however, our first President quickly came to the conclusion that the executive would have to play the primary role in determining the nation's foreign policy.

\section{A. WAR POWERS}

War remains one of the most hotly disputed questions in constitutional law today. Some claim that the original understanding of the Constitution requires Congress to authorize all wars because of its power to declare war. Defenders of the executive branch emphasize the modern practice of Presidents launching significant wars without congressional authorization. Opponents of this view have relied on a 1793 statement by George Washington rejecting a plea that the United States attack the Creek Indians. "The Constitution vests the power of declaring war with Congress," Washington wrote to Governor William Moultrie of South Carolina, "therefore no offensive expedition of importance can be undertaken until after they shall have deliberated on the subject, and authorized such a measure." 62 Some scholars claim this shows Washington's agreement that Congress must enact legislation authorizing all military hostilities abroad. David Currie, for example, concludes that the "first three presidents," Washington included, "took an appropriately narrow view of their authority as Commander in Chief," a view he believes was faithful to the decisions of the Constitutional Convention. ${ }^{63}$

War in the early years of the Republic was not so simple. The administration sought Congress's cooperation when it needed increases in the size of the army, military spending, or the approval of agreements-in other words, those areas where the Constitution specifically provided for a legislative role. When it came to political and military strategy, however, Washington and his advisors mostly acted alone. Under our first President, the United States waged war against only one enemy, the Indian tribes located in the neighborhood of present-day Ohio. By the time of the ratification, friction between Indians and American settlers in the West had grown, and some tribes had refused to respect the terms of the peace with Great Britain. ${ }^{64}$ British leaders, for their part, hoped that the Indians would create a buffer state that would limit American expansion in the Northwest. Washington and Knox pursued a peaceful settlement with the tribes, but

62. Letter from Washington to Moultrie (Aug. 28, 1793), in 33 WRITINGS OF WASHINGTON, supra note 8 , at 73 .

63. David Currie, Rumors of War: Presidential and Congressional War Powers, 67 U. CHI. L. REV. 1, 2 (2000).

64. See Richard H. KoHn, Eagle and Sword: THE Federalists and the CREATION OF THE MILITARY ESTABLISHMENT IN AMERICA, 1783-1802, at 92-93 (1975). 
they prepared for war.

In 1789 , it would have been impossible for Washington to conduct military operations without Congress's active cooperation. This was not because of the power to declare war; there simply were no troops for the President to command. After assuming office, Washington reported to Congress that the existing army numbered only 672 officers and soldiers, scattered across the frontier. By comparison, Indian tribes menacing Georgia could field 5,000 warriors for battle. ${ }^{65}$ Under the Articles of Confederation, Congress had established a force to protect the frontiers "from the depredations of the hostile Indians" and police the public lands. ${ }^{66}$ In order to wage any kind of campaign, Washington would have to convince Congress to create a standing army. Living in a world with a large peacetime army and navy, we easily forget that chief executives of the eighteenth and nineteenth centuries had to seek ad hoc creation of a military force to fight any significant conflict. Congress's power of the purse and its authority to establish the military gave it a functional veto over any war and the ability to limit the nature of a conflict through the structure of the armed forces.

Congress quickly provided for the continued existence of a small permanent army. It also gave the President the authority to call out the state militia "as he may judge necessary" to protect settlers against "the hostile incursions of the Indians," Indian tribes. Aside from the militia authorization, Congress placed no restrictions of any kind on the use of the regular armed forces. The natural conclusion is that Congress recognized the President's powers as Commander-in-Chief to decide how to use the forces once they had been created. It is possible that Congress believed it was simply re-authorizing the army under the same conditions and purposes as that of the Confederation Congress, but we need not depend on inference. During the House debates, some in Congress objected to the bill's language because they believed it gave the President the unconstitutional power to start a war. ${ }^{68}$ Others wanted to add language to the bill to force a more aggressive strategy on the administration. Madison argued that Congress should not specify where troops should be based nor for what purposes they should be used. "By the Constitution, the President has the power of employing these troops in the protection of those parts [of the country] which he thinks requires them most." 69

Washington's actions in 1789 show that he believed that once Congress

\footnotetext{
65. Id. at 96.

66. 1 ANNALS OF CONG., supra note 18 , at 715.

67. Act of Sept. 29, 1789, 1 Stat. 95.

68. KOHN, supra note 64, at 97.

69. 1 ANNALS OF CONG., supra note 18 , at 724 .
} 
created the military, he had the authority to decide whether and how to use it. Even before Congress had approved the continuation of the regular army, the administration ordered General Josiah Harmar to begin disrupting Indian activities in the area of what would become Cincinnati. In October, Washington ordered Arthur St. Clair, governor of the Northwest Territory, to mobilize 1,500 militiamen and launch punitive operations against the Wabash and Illinois Indians, should they reject diplomatic overtures. ${ }^{70}$ These troops were not enough. Federalists had long thought that state militias were unreliable and badly trained and performed poorly. Knox believed that at least 2,500 regular troops would be needed to quell the hostile Indian tribes in the Ohio region. ${ }^{71}$ A few months later, Washington requested an increase in the permanent army to 1,200, and Congress obliged. Continuing its practice from 1789, Congress passed neither an authorization of hostilities nor a restriction on the use of regular troops. ${ }^{72}$

Washington settled on war with the Indians in the Ohio region that summer. On June 7, 1790, Washington ordered Harmar and St. Clair to organize a punitive expedition into Indian territory to destroy bandits who were harassing settlements and apply pressure for a peace agreement. Washington soon expanded his aims: to field an army of 2,000 troopsroughly 1,600 of them militia-to attack the major villages of the Ohio tribes and to construct a permanent garrison to block their ties to the British. $^{73}$ As military historian Richard Kohn has written, the "2,000 man, two-pronged expedition fully committed the military, political, and moral prestige of the United States government." 74 Washington informed Congress about the scope of the Indian problems to justify increases in the army and the right to call out the militia, even going so far as to forward copies of his correspondence with St. Clair. ${ }^{75}$ But he sought no authority from Congress for his plan to drive more than 150 miles into enemy territory.

The offensive met with disaster. In October, Harmar's expedition lost about 200 men in a battle with the Indians and withdrew back to base, leaving its dead, wounded, and arms behind. When news arrived in Philadelphia, disgust reigned. Washington ordered another offensive by a new army of 3,000 troops with plans to construct a series of forts throughout the Indian territories. He informed Congress of his intentions in a December 8, 1790, speech and requested another increase in the size and

\footnotetext{
70. KOHN, supra note 64 , at 98 .

71. Id. at 96 .

72. Act of Apr. 30, 1790, 1 Stat. 119.

73. KOHN, supra note 64 , at 103.

74. Id. at 104 .

75. See, e.g., Letter from George Washington to House of Representatives (Sept. 16, 1789), in 1 ANNALS OF CONG. supra note 18, at 927-28.
} 
funding of the army. ${ }^{76}$ Some members of Congress disliked the strategy, and others opposed the extra spending, but news of Indian massacres on the frontier overrode any opposition. The second expedition fared even worse: on November 4, a surprise attack by a force of 1,000 Indians completely destroyed St. Clair's force. The regular American army ceased to exist, and the western United States was laid open to attack-it was the most devastating American military defeat since the early days of the Revolution. ${ }^{77}$

When the news arrived in December 1791, the capital was stunned. Washington came under withering attack, and critics accused the administration of mismanagement, poor strategy and policy, and a failure of leadership. Washington and Knox decided to escalate with a large, professional army that could permanently defeat the tribes. Washington did not seek statutory authorization for offensive operations or a declaration of war, nor did he seek congressional ratification of his strategy, but he needed legislative cooperation to expand the military. Washington sent Congress a flood of information about the failed St. Clair expedition, conditions in the Northwest, and a request to quintuple the size of the standing army and triple military expenditures to roughly $\$ 1$ million a year. Jeffersonians in Congress viewed the new military as yet another piece of the Hamiltonian plan to duplicate the corrupt British political, economic, and military system. Although opposition was fierce, and public dissatisfaction with the administration's Indian policy was widespread, Congress gave Washington what he requested. It placed no limits on the use of the troops but did include a new restriction-that the troops be demobilized "as soon as the United States shall be at peace with the Indian tribes." 78 Jeffersonians also included some bitter medicine by conducting an investigation into the St. Clair disaster and issuing a report attacking the administration for mismanagement. ${ }^{79}$

The 5,000-man army brought victory. Washington ordered General "Mad Anthony" Wayne to undertake offensive operations against the Indians (he was even authorized to attack the British forts in the area, if assured of "complete success"). Diplomatic overtures failed because their success and British encouragement had convinced the tribes to seek complete American withdrawal from the Ohio region. Wayne spent all of 1792 and early 1793 assembling and training his army, even as Jeffersonians in Congress attacked the administration's strategies and attempted to cut the size of the regular army in half. In August 1794,

\footnotetext{
76. 2 ANNALS OF CONG. 1772 (1790).

77. KOHN, supra note 64, at 115-17.

78. Protection of The Frontiers of The United States by Raising Additional Troops, 2 Cong. Ch. 9, 1 Stat. 241 (1792).

79. KOHN, supra note 64 , at 116-24.
} 
Wayne won a decisive victory at the Battle of Fallen Timbers, which permanently broke Indian military resistance in the area. Historians today credit the battle with opening up large-scale settlement of the Northwest Territory and ending British efforts to hem in American expansion. It was a resounding success for Washington's Indian policy and vindicated his reliance on a professional military establishment.

Washington's success in the Indian wars did not follow a simple process of Congress first declaring war, and the executive then implementing the war policy. Congress never authorized offensive military operations; at most, it had allowed the President to call out the state militia to defend settlers from Indian attacks. A more complex process took hold, one characterized by presidential initiative and leadership, balanced by congressional control over the size and shape of the military. Washington and his advisors decided on the mix of negotiations and force, the timing of offensive attacks, and the overall strategy. Congress respected Washington's discretion to make these decisions, but it had a functional veto through its control over the organization and growth of the military. If it had wanted to favor diplomacy, Congress could have limited the army to 1,000 troops or fewer. Congress's power to control the President's initiatives came not through formal legislation or declarations, but via its monopoly over funding.

In most areas of domestic affairs, Washington played a relatively passive role and left matters to Congress, but not so with military affairs. From the very first bill continuing the 700-man army through the expansion to a regular army of 5,000 , the Washington administration took the initiative without fail. Each increase was first developed and then proposed by the executive branch, and while some in Congress had a different view-particularly over the balance between regular army and militia troops - the legislature as a whole never refused the Commander-in-Chief's requests. In the Republic's earliest years, Washington set an example of executive leadership upon which future Presidents would draw. At the same time, Washington took all of the political responsibility for the success or failure of the Indian wars, and Congress displayed little eagerness to fight him for it. Blame for the crushing defeat of St. Clair's forces was laid wholly at the administration's doorstep, but at the same time Congress deferred to the President's request for more troops to undertake even more ambitious operations. Presidential power allowed Washington to take the initiative when the nation's security and interests demanded it, but it also bore with it the heavy responsibility for failure as well as success.

Some might argue that these military conflicts have little constitutional significance because they involved the Indians, rather than nations. ${ }^{80}$ But by

80. See ABraham Sofaer, War, Foreign Affairs and Constitutional Power: The 
all indications, the Washington administration acted as if the normal rules of war and diplomacy applied. In cabinet meetings on military strategy, President Washington declared that "we are involved in actual war!"81 Indians in the Ohio region could field a military force as large as the United States Army, while the tribes in Georgia had a force five times greater at their command. When the Washington administration wanted to reach a negotiated settlement, it considered the agreements to be treaties and submitted them to the Senate for consent. ${ }^{82}$ Three decades would pass before the Supreme Court classified the Indian tribes as semi-sovereign, dependent nations. ${ }^{83}$ Conflict with the Indians was critical to America's national security, and the government treated it as the war that it was.

\section{B. CONSENT BUT NOT ADVICE}

On Saturday, August 22, 1789, even before Congress had created a Secretary of State, Washington personally visited the Senate to take its temperature on a possible Indian treaty. With Knox in tow, the President came prepared with a short paper on the problem and a list of seven questions he wanted answered by the Senate. As Vice President Adams read the questions aloud, street noise from outside disrupted the proceedings. Adams repeated the questions again. Senators asked that all relevant treaties and related documents be read aloud, and then asked for the questions again. Senator William Maclay of Pennsylvania moved that the whole matter be referred to a special committee. Washington lost his temper, jumped up, and left the chamber with the words: "this defeats every purpose of my coming here." Some report that Washington muttered as he stormed out that "[I] would be damned if [I] ever went there again." 84 Apparently, he returned the very next Monday, and the Senate agreed to all of his questions, but no President, Washington included, ever again consulted in person with the Senate.

By trying to include the Senate, Washington revealed that it was illdesigned to play a formal role in treaty negotiations. Because international politics required secrecy and subtlety, the Senate's formal function in the future was limited to consent, but not advice. This episode also demonstrated, as Stanley Elkins and Eric McKitrick have observed, that the President was more than simply a prime minister. To be effective, the office required a certain level of prestige and independence that precluded a personal appearance before the Senate for permission to conduct

ORIGINS 119 (1976).

81. Errors of Government Towards the Indians (Feb. 1792), in 31 WRITINGS OF GEORGE WASHINGTON, supra note 8 , at 491.

82. See, e.g., Fort Harmar Treaty of 1789,7 Stat. 28; and Creek Treaty of 1790, 7 Stat. 35 .

83. See Johnson v. M'Intosh, 21 U.S. 543 (1823).

84. ELKINS \& MCKITRICK, supra note 21 , at 55-58. 
negotiations. Washington's instinct to take firm control over the nation's diplomatic relations cemented this institutional dynamic. Upon taking office, Washington began to issue directions to John Jay, then Foreign Minister under the Articles of Confederation, and immediately dictated diplomatic relations with other nations. ${ }^{85} \mathrm{He}$ assigned ambassadors to their missions, subject to Senate confirmation, and issued their instructions, removed them when necessary, and sometimes sent special envoys without senatorial advice and consent. ${ }^{86}$ In creating and funding the State Department, the first Congress recognized the President's special rights in foreign affairs by not delegating any duties to the Secretary of State other than those assigned to him by the President. As Sai Prakash and Michael Ramsey have argued, there would have been no need for the Secretary if the President did not already have a pre-existing foreign affairs power. ${ }^{87}$ Congress funded the department simply by appropriating a lump sum and leaving pay and employee grades to executive discretion.

Washington wanted to protect his authority to set the rank of diplomatic officials and asked the Secretary of State for his opinion. Jefferson responded, "The transaction of business with foreign nations is executive altogether." 88 The only exceptions were those functions given to the Senate, which were "to be construed strictly" in favor of the President's authority. Which envoys to send, where to send them, their diplomatic grade, and their instructions, both public and secret, Jefferson concluded, "all this is left to the President; [the Senate] is only to see that no unfit persons be employed." 89 The stuff of ambassadorial rank and negotiating records may seem trivial today, but in the eighteenth century they were the main instruments of foreign policy. Nations sent ambassadors on missions to negotiate agreements with instructions that left them a few goals and great flexibility on the terms; an ambassador's diplomatic rank signaled his nation's attitude toward a country. In 1794, Washington sent John Jay, the former foreign minister and chief justice at the time, to Britain with instructions to reach the best settlement possible of America's outstanding differences. His choice sent a strong signal that the United States wanted an amicable relationship. Echoing Madison's arguments during the removal debates, Jefferson believed these decisions fell within the President's authority because foreign affairs remained executive in nature.

Jefferson would regret his support of executive authority as he came to

85. See Saikrishna Prakash \& Michael Ramsey, The Executive Power over Foreign Affairs, 111 YALE L.J. 231, 299-300 (2001).

86. See SOFAER, supra note 80 , at $65-78$.

87. See Prakash \& Ramsey, supra note 85 , at $300-02$.

88. Thomas Jefferson, Opinion on the Powers of the Senate (Apr. 24, 1790), in 5 WrITINGS OF THOMAS JEFFERSON, supra note 26, at 161 .

89. Id. 
oppose Washington's foreign policies toward France and Great Britain. The beginning of the French Revolution in 1789 set off wars in Europe that would last a quarter-century. Eventually, the United States became entangled and barely escaped with its independence intact. But Washington kept the United States out of the conflict, giving the nation time to develop its strength and confidence. In guiding the young republic between the Scylla and Charybdis of Britain and France, he imposed a policy of neutrality based on the constitutional understanding that he held the authority to set foreign policy, interpret and even terminate treaties, and decide the nation's international obligations. Washington paid a steep price: his policies divided his government, sparked the creation of the first political party, and turned future presidential elections into partisan affairs. Neutrality in the European wars ruined Washington's hopes for a government ruled by consensus and left him disgusted with politics.

After the beheading of King Louis XVI, France declared war on Great Britain and Holland on February 1, 1793. ${ }^{90}$ Edmund Genet, the new regime's ambassador to the United States, arrived two months later. News of war threw the American government into a quandary over the 1778 treaties with France, which had been crucial to the success of the Revolution. Article 11 of the Treaty of Alliance called on the United States to guarantee French possessions in the Americas, which implied that the United States might have to defend France's West Indies colony (today's Haiti). ${ }^{91}$ Article 17 of the companion commercial treaty gave French warships and privateers the right to bring captured enemy ships as prizes into American ports. ${ }^{92}$ Article 22 prohibited the United States from allowing France's enemies to equip or launch privateers or sell prizes in American ports. ${ }^{93}$

Genet attempted to rouse the American people against Britain. Demanding that the United States honor the treaties, he authorized American ships to raid British shipping. The cabinet split over a response. Jefferson deeply hated Great Britain, admired the French Revolution, and suspected Hamilton of duplicating the British political system. For his part, Hamilton loathed the French Revolution, and his financial system depended on good relations with Britain. Upon learning of the French declaration of

90. For the relevant historical details, I have relied on ELKINS \& MCKITRICK, supra note 21, at 303-73; MCDONALD, The PRESIDENCY OF GEORGE WASHINGTON, supra note 6, at 113-37; Editorial Note, Jefferson's Opinion on the Treaties with France, reprinted in 25 THE PAPERS OF THOMAS JEFFERSON, supra note 34, at 597-602; and Letter from Alexander Hamilton to John Jay (Apr. 9, 1793), in 14 The PAPERS OF AlEXANDER HAMILTON, supra note 35, at 297, 298 n. 4. These events are also discussed in David P. Currie, The Constitution in Congress: The Third Congress, 1793-1795, 63 U. CHI. L. REV. 1, 4-16 (1996).

91. Treaty of Alliance, U.S.-Fr., art. 11, Feb. 6, 1778, 7 Bevans 777.

92. Treaty of Amity and Commerce, U.S.-Fr., art. 17, Feb. 6, 1778, 8 Stat. 12.

93. Treaty of Alliance, U.S.-Fr., art. 22, Feb. 6, 1778, 7 Bevans 777. 
war, Hamilton, "with characteristic boldness," immediately urged Washington to suspend or terminate the treaties. ${ }^{94}$ The young Treasury Secretary simply could not help meddling in the affairs of others, especially those of the Secretary of State. Hamilton believed that Britain's control of the seas and its trading system made good relations with London paramount. While a change in government did not automatically void treaties with another state, he argued that the uncertain status of the French government and the dangerous wartime situation allowed suspension of the treaties. ${ }^{95}$ While Jefferson agreed that military participation in the European war was out of the question, he believed the United States was obliged to fulfill the treaties. (Under the Articles of Confederation, he had served as minister to France.)

On April 18, Washington sent a list of thirteen questions to Hamilton, Jefferson, Knox, and Randolph and ordered a cabinet meeting for the next day - establishing a regular mechanism of presidential decision-making. ${ }^{96}$ Almost all of Washington's questions involved the interpretation of the 1778 treaties. Question four, for example, asked: "Are the United States obliged by good faith to consider the Treaties heretofore made with France as applying to the present situation of the parties?" Washington ordered them to give an opinion on whether Article 11 applied to an offensive war launched by France, whether the United States could both observe the treaties and remain neutral, and under what conditions the United States could suspend or terminate the treaties.

Washington's questions produced a deceptive unanimity in the cabinet. Everyone agreed that a proclamation of neutrality should be issued, but in order to assuage Jefferson's concerns, the word "neutrality" was not used. Indeed, given the United States' distance, its military weakness, and its strategic irrelevance to the European theatre, neutrality was the only realistic option. Two other questions received the same unanimity. The cabinet agreed that the President should receive Genet as France's ambassador, making the United States the first nation to recognize the government of revolutionary France. The members further agreed that consulting Congress was unnecessary. The executive branch would decide the nation's position on the European wars. Adjourning the meeting without reaching the other questions, Washington asked his advisers to submit written responses on whether to suspend or terminate the 1778 treaties.

No one in the cabinet disputed that the President held this power under

94. Notes on Washington's Questions on Neutrality and the Alliance with France (May 6, 1793), in 25 PAPERS OF THOMAS JEFFERSON, supra note 34, at 665-66.

95. See Letter from Hamilton to Jay (Apr. 9, 1793), in 14 THE PAPERS of AlexANDER HAMILTON, supra note 35 , at 297-98.

96. See Letter from Washington to Hamilton, Jefferson, Knox, and Randolph (Apr. 18, 1793), in 14 THE PAPERS OF ALEXANDER HAMILTON, supra note 35, at 326-27. 
the Constitution. On April 28, Jefferson, later joined by Randolph, argued that international law did not permit the suspension or annulling of a treaty because of a change in government. ${ }^{97}$ Because he believed that France was unlikely to ask the United States to defend the West Indies, Jefferson recommended that the administration do nothing. On May 2, Hamilton and Knox argued that the civil war in France allowed the United States to suspend the treaty, or even terminate it because of the new circumstances threatening American national security. ${ }^{98}$ They read the treaty to apply only to defensive wars, not to one in which France had attacked first. Telling Jefferson that he "never had a doubt about the validity of the treaty," Washington decided against suspension the next day. ${ }^{99}$ On the question of the West Indies, Washington decided to remain silent, a wise choice, as Jefferson's prediction proved correct and France did not seek American aid.

Washington issued his decision in a proclamation drafted by Randolph. ${ }^{100}$ Recognizing a state of war between France and the other European powers, he announced that the United States "should with sincerity and good faith adopt and pursue a conduct friendly and impartial toward the belligerant [sic] Powers." Washington further saw fit to "declare the disposition of the United States to observe the conduct aforesaid towards those Powers respectfully" and "to exhort and warn the citizens of the United States carefully to avoid all acts and proceedings whatsoever, which may in any manner tend to contravene such disposition." The proclamation also stated that the federal government would prosecute those who "violate the law of nations, with respect to the Powers at war." His proclamation was a determination that American obligations did not require entry into the war on the side of the French. After a year, Congress implemented his interpretation into domestic law by making it a crime for a citizen to violate American neutrality. ${ }^{101}$

Although the Continental Congress had negotiated and ratified the 1778 treaties, Washington never asked about its intentions. ${ }^{102}$ None of his cabinet members wanted to interpret the treaties in the light most favorable to France. Both Hamilton and Jefferson grounded their appeals in the national interest, international law, and common sense. Neither expressed a belief

97. Opinion on the Treaties with France (Apr. 28, 1793), in 25 THE PAPERS OF THOMAS JEFFERSON, supra note 34 , at $608-18$.

98. Letter from Hamilton \& Knox to Washington (May 2, 1793), in 14 THE PAPERS OF ALEXANDER HAMILTON, supra note 35 , at 367-96.

99. Notes on Washington's Questions on Neutrality and the Alliance with France, reprinted in 25 THE PAPERS OF THOMAS JEFFERSON, supra note 34, at 666.

100. 1 COMPIlation OF The MESSAges AND PAPERS OF THE PRESIDENTS: 1789 -1897, 156 (James D. Richardson ed., 1900).

101. Neutrality Act, 1 Stat. 381 (June 5, 1794).

102. See JaCK N. Rakove, The BEGinnings of National Politics: AN INTERPRETIVE History OF THE CONTINENTAL CONGRESS 113-18 (1979); and SAMUEL F. BEMIS, ThE DIPLOMACY OF THE AMERICAN REVOLUTION 58-69 (1957). 
that consultation with Congress or the Senate was necessary or advisable. Washington and his cabinet proceeded on the assumption that it was the province of the executive branch to interpret treaties, and so set foreign policy, on behalf of the United States. They even believed that the President had the authority to terminate the 1778 treaties. Hamilton argued that the President could terminate if necessary, but recommended only suspension. Fighting a rearguard action, Jefferson did not raise a constitutional objection. Even though Hamilton convinced Washington to declare neutrality, it is doubtful that Jefferson could have produced any other outcome-the United States simply was not going to enter the war on France's side, at least not for another two decades. ${ }^{103}$

The proclamation provoked one of the great constitutional debates in American history. In a series of newspaper articles that summer, Hamilton adopted the pseudonym of "Pacificus" to defend the President's constitutional authority. ${ }^{104}$ Hamilton began with the position that foreign policy was executive by its very nature. Congress was not the "organ of intercourse" with foreign nations, while the judiciary could only "decide litigations in particular cases." Declaring neutrality, therefore, must "of necessity belong to the Executive." It drew from the executive's authority as "the organ of intercourse between the Nation and foreign Nations," as "interpreter of the National Treaties in those cases in which the Judiciary is not competent," and as enforcer of the law, "of which treaties form a part." Hamilton argued that treaties, as well as the rules of international law, were part of the laws to be carried out by the executive, and "[h]e who is to execute the laws must first judge for himself of their meaning." Last, but not least, Hamilton believed the executive could declare neutrality because of its "Power which is charged with the command and application of the Public Force."

Basing his claims on the constitutional text, Hamilton argued that the President's authority derived from Article II, Section 2's grant of the executive power. The Constitution already made the President Commanderin-Chief, maker of treaties with the advice and consent of the Senate, receiver of ambassadors, and executor of the laws. But "it would not consist with rules of sound construction to consider this enumeration of particular authorities as derogating from the more comprehensive grant contained in the general clause." Article II's enumeration of powers "ought . . . to be considered as intended ... to specify and regulate the principal articles implied in the definition of Executive Power; leaving the rest to flow from the general grant of that power ...." For Hamilton, the Senate's role in making treaties was only a narrow exception from the general grant of

103. Prakash \& Ramsey, supra note 85 , at 325-27.

104. See Alexander Hamilton, Pacificus No. 1, reprinted in 15 THE PAPERS OF AleXANDER HAMILTON, supra note 35, at 33-43. 
executive power to the President and "ought to be construed strictly." When the Constitution sought to transfer traditionally executive powers away from the President, it did so specifically, as with the power to declare war. "The general doctrine then of our constitution is, that the Executive Power of the Nation is vested in the President," Hamilton concluded, "subject only to the exceptions and qualifications which are expressed in that instrument."

Madison, however, expressed surprise and concern over the President's Proclamation of Neutrality. In a letter to Jefferson, Madison claimed Hamilton had talked Washington into an "assumption of prerogatives not clearly found in the Constitution and having the appearance of being copied from a Monarchical model."105 His immediate criticism was that the proclamation intruded on Congress's power to declare war. Jefferson explained that although he had agreed in the cabinet that the President could declare neutrality without consulting Congress, he nonetheless had constitutional concerns. When Hamilton's Pacificus essays-defending the President's power to declare neutrality-appeared in the press, Jefferson begged Madison: "For God's sake, my dear Sir, take up your pen, select the most striking heresies and cut him to pieces in the face of the public."106

Under the pseudonym "Helvidius," Madison took issue with every point of Hamilton's constitutional arguments. ${ }^{107} \mathrm{He}$ dismissed Locke's and Montesquieu's classification of foreign affairs as executive in nature because they were "evidently warped by a regard to the particular government of England." Making treaties and declaring war were legislative powers because they had the force of law; therefore, the President could not exercise them. "The natural province of the executive magistrate is to execute laws, as that of the legislature is to make laws," Madison wrote. "All his acts therefore, properly executive, must presuppose the existence of the laws to be executed." The Constitution vested the power to declare war in Congress and gave the Senate an equal share in the treaty power, confirming that they set private rules of conduct made the law of the land by the Supremacy Clause. To allow the President a share of the legislative power "is an absurdity - in practice a tyranny." 108

Madison's deeper argument was that placing the power to start and wage war in the same hands risked tyranny. "Those who are to conduct a war cannot in the nature of things be proper or safe judges whether a war

105. Letter from Thomas Jefferson to James Madison (June 13, 1793), in 26 THE PAPERS OF THOMAS JEFFERSON, supra note 34, at 272-74; see also Letter from Thomas Jefferson to James Madison (June 23, 1793), in 26 THE PAPERS OF THOMAS JEFFERSON, supra note 34, at 346.

106. Letter from Jefferson to Madison (July 7, 1793), in THE PAPERS OF THOMAS JEFFERSON, supra note 34 , at $443-44$.

107. See James Madison, Helvidius Nos. 1-5, reprinted in 15 THE PAPERS OF JAMES MADISON 66-120 (Thomas Mason ed., 1985).

108. Id. at 69 . 
ought to be commenced, continued, or concluded."109 Why? Because, according to Madison, "war is in fact the true nurse of executive aggrandizement." 110 In war, "physical force is to be created," "the public treasures are to be unlocked," "the honors and emoluments of office are to be multiplied," and "laurels are to be gathered," and all are to be placed at the disposal of the executive. It is an "axiom," therefore, that "the executive is the department of power most distinguished by its propensity to war." Pacificus' broad reading of the vesting of the executive power in the President, Madison retorted, was nothing less than an effort to smuggle the British Crown into the Constitution.

History has looked more favorably on Hamilton's arguments than Madison's. Helvidius claimed rather unpersuasively that foreign affairs were legislative in nature or shared between the branches, and he never directly addressed Hamilton's argument about Article II's vesting of the executive power in the President. ${ }^{111}$ It was difficult for Madison to deny that Article II granted the President some unenumerated powers, in light of his arguments during the removal debate. Madison ultimately rested on the narrower point that the President could not interpret treaties in a manner that prevented Congress from exercising its own plenary constitutional power to declare war. ${ }^{112}$ The Proclamation, however, did not prevent Congress from declaring war, if it wished. Washington's actions only had the effect of preserving the status quo.

Despite the partisan divisions, the Helvidius-Pacificus debates and the neutrality controversy demonstrate some common ground. No one doubted that the President held the initiative in foreign policy, nor did Madison take serious issue with the idea that the executive had the power to interpret or even terminate treaties. Madison and Jefferson were making a broader argument against unenumerated executive powers and the structural point that those powers could not be used to supplant Congress's own authorities. Hamilton agreed with this up to a point, noting that Congress's power to declare war gave it the final word on whether the United States was in a state of war with another country. The Constitution's explicit grant of a specific power to Congress prevents the President from usurping that power, just as Congress cannot use its own plenary powers to invade the proper scope of the executive's powers. We can see this balance in Washington's unsuccessful efforts to prosecute individuals for violating the

109. Id.

110. Id. at 108 .

111. See ElKINS \& MCKITRICK, supra note 21, at 362 (noting Madison's weak performance); but $c f$. LANCE BANNING, THE SACRED FiRE OF LIBERTY: JAMES MADISON AND THE FOUNDING OF THE FEDERAL REPUBLIC 527 n. 18 (1995) (arguing that Madison demolished Hamilton's arguments).

112. Madison, Helvidius No. 2, reprinted in 15 THE PAPERS OF JAMES MADISON, supra note 105 , at 82 . 
proclamation. Only Congress could regulate the conduct of citizens within the United States, and it was not until Congress enacted criminal legislation that prosecutions could succeed. ${ }^{113}$

The proclamation set one of the most important precedents for executive power: Presidents henceforth would exercise the initiative in foreign affairs. Jefferson and Madison wanted to limit the executive's powers where they were perhaps needed most-in foreign affairs. But the growth of the nation and its interests would place increasing pressure on their constitutional vision. As the effect of foreign affairs on the nation grew, the powers of the office would respond to keep pace. Still, Hamilton's view required no prerogative, no ability of the President to act outside of the Constitution when necessity demands. He believed that the Constitution gave the President, through the grant of "the executive power" of the government, all of the authority necessary to handle exigencies and unforeseen circumstances. Jefferson and Madison, on the other hand, fought against an elastic reading of presidential power, and, as Jefferson's opinion on the bank showed, generally in favor of a strictly limited federal government. This would force them, surprisingly, into the position of relying on the theory of an extra-constitutional presidential prerogative when they assumed power in 1800 .

\section{EXECuTIVE PriviLEGE}

Washington's largely successful efforts to keep the United States out of the European wars called on him to define executive power one last time in his last year in office. The occasion was the Jay Treaty, which sought to resolve long-term issues plaguing Anglo-American relations. Great Britain continued to occupy forts within the Northwest Territory, which under the 1783 peace treaty it was required to evacuate, on the ground that British creditors could not recover pre-revolutionary loans made to Americans. British officials in the area caused constant trouble by encouraging local Indians to oust the Americans from the territory. A more immediate difficulty was Britain's naval war against France. American merchants and shippers were profiting handsomely by selling to both belligerents, with the trade between the Caribbean colonies of the two great powers being especially lucrative. In 1793, Britain declared an embargo against France, seized neutral ships carrying contraband including food, and captured

113. The Washington administration attempted to prosecute violators of neutrality in the absence of a statutory crime. See Stewart Jay, Origins of Federal Common Law, Part One, $133 \mathrm{U}$. PA. L. REV. 1003, 1039-93 (1985). The issue was not finally resolved by the Supreme Court until 1812, in United States v. Hudson \& Goodwin, 11 U.S. 32 (1812), in which the Court held that the federal government could not prosecute individuals for non-statutory common law crimes. See Gary D. Rowe, The Sound of Silence: United States v. Hudson \& Goodwin. The Jeffersonian Ascendancy, and the Abolition of Federal Common Law Crimes, 101 YALE L.J. 919 (1992). 
sailors on American ships who were allegedly British deserters. Later that year, Britain imposed a blockade on the French West Indies trade, leading to the immediate seizure of 250 American merchant ships in the area. ${ }^{114}$

Britain's seizures of American shipping stoked a war scare. Congress rejected proposals for a 15,000-man army but agreed to a temporary embargo on Great Britain and the construction of six daring new frigates, America's first blue-water navy. After news came that Britain had rescinded its embargo of the French West Indies, Washington sent Chief Justice Jay to London as a special envoy to settle all outstanding disputes. Jay reached an agreement in November 1794, which arrived in the United States in March. In Jay's Treaty, Britain agreed to evacuate the northwestern forts, allow limited American trade with the West Indies, grant most-favored-nation tariff treatment to American imports, and create an international commission (the first of its kind) to arbitrate the debt claims, the seizures of American ships, and the U.S.-Canada border. Jay failed to reach any settlement on slaves carried off by British forces at the end of the Revolution or to secure British commitment to the principle that neutral ships could carry goods to any of the belligerents. Under the circumstances, it was probably the best deal possible: It ended the British threat to the western territories and kept the peace for another seventeen years. Many historians today consider the Jay Treaty a success and another example of Washington's leadership. ${ }^{15}$

Opposition by Jefferson's supporters was so fierce that it cemented the emergence of the two-party system in American politics. In June 1795, a 20-10 Federalist majority in the Senate barely approved the treaty (except for the provision on the West Indies trade, which it rejected). Washington ratified the treaty in August. When the text became public, large protests erupted throughout the country. Jeffersonians sought to capitalize by blocking measures in the House needed to implement the treaty, such as changes in tariff schedules and appropriations for the compensation of British claims. Hoping to reveal embarrassing details within the administration, the House voted 62-37 in March 1796 to request all of the papers related to Jay's mission. On earlier occasions, the administration had supplied papers in response to congressional investigations, one into St.

114. These events are described in JERALD A. COMBS, THE JAY TREATY: POLITICAL Battleground of THE FoUnding Fathers (1970); SAMUEL FlaGG BEMIS, JAY'S TREATY (1923); Alexander DeConde, Entangling Alliance: Politics \& Diplomacy Under GEORGE WASHINGTON (1958); BRADFORD PERKINS, THE FIRST RAPPROCHEMENT: ENGLAND AND THE UNITED STATES, 1795-1805 (1955); and more recently by Todd Estes, The Art of Presidential Leadership: George Washington and the Jay Treaty, 109 VA. MAG. OF HISTORY AND BIOG. 127 (2001); and ChaRles RitCHESON, AFtermath OF REVOlution: BRITISH POLICY TOWARD THE UNITED STATES, 1783-1795 (1971).

115. ElKins \& MCKITRICK, supra note 21 , at 412; MCDONALD, ThE PRESIDENCY of WASHINGTON, supra note 6 , at 140. 
Clair's defeat by the Indians and the second into allegations of financial irregularities by Hamilton. Although he cooperated with Congress on these occasions, Washington had taken the view that he could refuse if the disclosure of the information would harm the public interest. ${ }^{116}$ Even if the Presidency could lay claim to a right of executive privilege, the benefits of maintaining harmony with the legislature and public confidence in government would usually prevail.

This time, Washington chose to place the confidentiality of executive deliberation above good relations with Congress. Only five days after the House sent its request, Washington responded that it had no constitutional right at stake. To allow the House to see the papers would create "a dangerous precedent." 117 The Constitution had vested the power to make treaties in the President, with the advice and consent of the Senate, because of the need for secrecy in diplomatic relations. Expanding the House's role would undermine the nation's ability to keep secrets and make it difficult, if not impossible, to manage foreign affairs effectively.

Washington observed that the Framers had explicitly rejected any role for the House in treaty-making, and had included the Senate to protect state interests - $a$ fact he knew well as President of the Constitutional Convention. The House had an obligation to implement the treaty, as it had already carried into effect without question all previous ones. If the House had a legitimate constitutional claim to the papers, Washington might comply, but here he need not consider it. "It does not occur that the inspection of the papers asked for can be relative to any purpose under the cognizance of the House of Representatives," Washington wrote, "except that of an impeachment which the resolution has not expressed."118 Jeffersonians were shocked, Federalists overjoyed. Efforts to block the treaty soon lost steam, in part because of Washington, in greater part because the restoration of the international carrying trade sparked an economic boom.

Debate has continued to this day over whether Washington correctly refused the House's demand for information. He did not describe his nondisclosure as "executive privilege" or ground it in a broad theory of the President's right to protect internal communications and advice, as the Supreme Court would in the Watergate tapes case. ${ }^{19}$ Washington kept his

116. PHELPS, supra note 1 , at 174-75.

117. 35 WRITINGS OF GEORGE WASHINGTON, supra note 8 , at 2-5.

118. Id.

119. See United States v. Nixon, 418 U.S. 683 (1974). For critical discussion, see Akhil R. Amar, Nixon's Shadow, 83 MINN. L. REV. 1405 (1999); Michael S. Paulsen, Nixon Now: The Courts and the Presidency After Twenty-five Years, 83 MINN. L. REV. 1337 (1999). For analysis of the rise of executive privilege, see MARK J. RozELL, EXECUTIVE PrIVILEGE: PrESIDENTIAL Power, SECRECy, AND ACCOUNTABILITY (2002); and LouIS Fisher, The Politics OF EXECUTIVE PRIVILEGE (2003). 
claim carefully circumscribed to the House's exclusion from treaty-making. He had turned over all of the papers to the Senate as part of the process of advice and consent. Washington, however, clearly believed that his right to withhold information from Congress extended beyond that narrow context. In 1794, the Senate requested all diplomatic communications between the American envoy to France (who was then Gouverneur Morris) and the Secretary of State. Attorney General William Bradford advised that the President could withhold correspondence whose revelation would harm the public interest, and the other members of the cabinet agreed. Washington provided the correspondence but informed the Senate that he had not given them material that, in his judgment, ought not to be publicly communicated. ${ }^{120}$

Washington's arguments have broad implications. He consciously ignored the House's legitimate constitutional right to gather information to appropriate money and regulate trade. ${ }^{121}$ To say that the House had a right to the documents only if it were considering impeachment was an overstatement, to say the least. Washington based his refusal in part on the need for secrecy in foreign affairs, referring to the harm that would result if the government could not act with discretion in negotiating agreements. While limited to treaties, Washington's decision would provide the foundations for future Presidents to expand their right to keep from Congress and the courts any information the disclosure of which would harm the national interest.

\section{Conclusions}

Our Constitution usually grants those elected to the Presidency their legitimacy; with Washington, it was the reverse. His standing as the Father of the Country bestowed legitimacy on the Constitution. It is hard to imagine another member of the founding generation who could guarantee that the Constitution would overcome the centrifugal forces of its early years. Washington placed at the service of the young government his record as the general who had won the nation's independence, and his reputation for republican virtue etched in memory when he had stepped down from command.

Washington was not the greatest simply because he was the first. He did more than serve as the ceremonial head of government. Understanding instinctively that his actions set the example for his successors, Washington

120. Abraham D. Sofaer, Executive Privilege: An Historical Note, 75 CoLum. L. REv. 1318 (1975).

121. On this point, see John Yoo, The Powers of War and Peace: The Constitution AND FOREIGN AFFAIRS AFTER 9/11, at 242-43 (2005). 
made decisions that fulfilled the Federalists' hope for independence and energy. He reserved to the executive control over the selection of government nominees; treated all subordinates as part of a unitary executive branch, with himself at the top; and fought to keep the internal deliberations of his advisers confidential.

Washington believed he had to interpret the Constitution independently in executing his powers, whether by signing proposed bills or implementing those on the books. When it came time to enforce national laws and policies, Washington led the troops personally to demonstrate the energy and authority of the new government. In foreign affairs, Washington read the Constitution to give him the executive's traditional leading role, including the interpretation of treaties and international law, the deployment of military force, and the conduct of diplomatic relations. He moved forcefully to keep the nation out of the European wars and to reach a settlement with Great Britain.

Washington demonstrated that a President could not succeed without his constitutional powers. The Framers did not account for, and were openly hostile to, political parties. They believed that a President should stand above parties, which were seen as temporary factions assembling against the national interest. ${ }^{122}$ From the very beginning, Washington saw his office as advancing a set of policies, a program which required the cooperation of the executive and legislative branches. Washington's administration devised the national banking system and the assumption of debts. It developed the policy of neutrality in the wars between Great Britain and France and set the nation on a hostile military course with the Indians. Washington understood the Presidency as giving him, not Congress, the initiative in defining foreign and domestic security policy.

Institutional independence included recognition of the other branches' prerogatives. Only the legislature could create the bank, approve the Jay Treaty, or fund the troops on the frontier. While Washington was dismayed at the open partisanship of the Jeffersonian opposition, his administration began the first experiments in the coordination of executive and legislative branches through a common political party. Washington would even recognize perhaps the ultimate limitation on the Presidency. By stepping down after two terms, Washington introduced a republican rotation in office, a precedent unbroken until Franklin D. Roosevelt, which proved to be a political bulwark against executive tyranny. By combining constitutional independence with constitutional self-control, Washington set the example of a republican executive that his successors would follow.

122. See, e.g., RalPh Ketcham, Presidents above Party: The First American PRESIDENCY, 1789-1829 (1984). 